\title{
ABREVIASI BAHASA PRANCIS PADA MEDIA SOSIAL TWITTER: SUATU KAJIAN MORFOLOGI
}

\author{
Widianti Eka Pratiwi ${ }^{1}$, Agus Nero Sofyan ${ }^{2}$ \\ ${ }^{1,2}$ Pascasarjana Fakultas Ilmu Budaya Universitas Padjadjaran \\ widianti14001@mail.unpad.ac.id \\ sofyanagusnero@gmail.com
}

\begin{abstract}
This research has a purpose to describe a morphological process called abbreviation. Abbreviation is a shortened form of a written word or phrase used in place of the whole word or phrase. This research uses descriptive qualitative method. The data are tweets in French which were taken on November 10 from Twitter. Overall, from the tweets those were found, there are twenty tweets which contain some words in abbreviated form. The result shows that there are five kinds of abbreviations that exist in those forty tweets, there are apocope, aphérèse, syncope, siglè, and acronyme. The most used abbreviation form is apocope which can be found in 14 tweets, meanwhile the least used one is aphérèse which is available in 4 of forty tweets.
\end{abstract}

Keywords: abbreviation, tweet, twitter, French

\section{PENDAHULUAN}

Komunikasi adalah proses pertukaran informasi dari seseorang ke orang yang lainnya. Ketika berbicara tentang komunikasi di era milenial ini, tidak lengkap rasanya jika tidak melibatkan peran internet. Internet adalah salah satu teknologi yang berkembang pesat dan sangat membantu manusia dalam berkomunikasi. Semakin berkembangnya zaman, semakin banyak pula perkembangan yang dialami oleh internet. Sekarang ini, kita dapat berhubungan atau berkomunikasi ataupun berbagi informasi dengan orang lain meskipun dipisahkan oleh jarak yang sangat jauh, salah satu perantaranya adalah melalui jejaring sosial.

Kaplan, dkk (2010) mendefinisikan media sosial sebagai sebuah kelompok aplikasi berbasis internet yang dibangun di atas dasar ideologi dan teknologi Web 2.0 dan memungkinkan penciptaan dan pertukaran user-generated content. Media sosial terdiri dari berbagai bentuk yang berbeda, seperti social network, forum internet, weblogs, social blogs, micro blogging, wikis, podcasts, gambar, video, rating, dan bookmark sosial. Menurut Kaplan, dkk ada enam jenis media sosial: proyek kolaborasi (misalnya, wikipedia), blog dan microblogs (misalnya, twitter), komunitas konten (misalnya, youtube), situs jaringan sosial (misalnya facebook, instagram), virtual game (misalnya world of warcraft), dan virtual social (misalnya, second life).

Jejaring sosial adalah situs dimana setiap orang bisa membuat laman pribadi dan kemudian terhubung dengan orangorang di seluruh dunia untuk berbagi informasi dan berkomunikasi. Beberapa jejaring sosial terbesar antara lain facebook, twitter, dan instagram. Jika media tradisional menggunakan media cetak, maka media sosial menggunakan internet. Media sosial mengajak siapapun yang tertarik untuk memberikan komentar dan berbagi informasi dalam waktu cepat dan tak terbatas. 
Blog, jejaring sosial dan Wiki adalah beberapa bentuk media sosial yang paling umum digunakan oleh masyarakat di seluruh dunia. Saat teknologi internet dan telepon seluler makin maju maka media sosial pun ikut tumbuh dengan pesat. Kini untuk mengakses twitter misalnya, bisa dilakukan dimana saja dan kapan saja hanya dengan menggunakan telepon seluler. Hal ini mengakibatkan cepatnya arus informasi berkembang, tidak hanya di negara-negara maju, namun juga di Indonesia. Karena cepatnya perkembangan media sosial, kini peranan media massa konvensional dalam menyebarkan berita pun mulai tergantikan.

Twitter adalah salah satu layanan jejaring sosial yang memungkinkan penggunanya untuk membaca pesan atau informasi terkini berbasis teks. Di dalam jejaring sosial twitter, ditemukan beragam variasi bahasa. Ragam bahasa atau sering disebut sebagai variasi bahasa terjadi tidak hanya karena penutur yang tidak homogen, tetapi juga karena kegiatan interaksi yang dilakukan masyarakat sangat beragam. Keragaman bahasa makin bertambah apabila bahasa tersebut digunakan oleh penutur yang sangat banyak dan dalam wilayah yang sangat luas (Wulandari, 2016).

Karena twitter membatasi penggunanya untuk menggunakan 280 karakter dalam setiap tweet, para pengguna dituntut untuk menulis informasi atau pesan secara singkat dan jelas sehingga ditemukan banyak sekali penyingkatan atau abreviasi.

Penelitian tentang abreviasi sudah pernah dilakukan oleh Diza Juanita yang melakukan analisis kontrastif abreviasi bahasa Indonesia dan abreviasi bahasa Prancis. Namun, belum ada penelitian yang secara khusus membahas tentang abreviasi dalam bahasa Prancis sehingga dapat dikatakan penelitian mengenai bentuk abreviasi bahasa Prancis pada media sosial Twitter ini merupakan penelitian yang mengisi rumpang yang baru sehingga sangat perlu dikemukakan dan dibahas lebih lanjut.

Menurut Kridalaksana (2008: 1) Abreviasi adalah proses morfologis berupa penanggalan satu atau beberapa bagian leksem atau kombinasi leksem sehingga terjadi bentuk baru yang berstatus kata. Abreviasi ini menyangkut penyingkatan, pemenggalan, akronimi, kontraksi, lambang huruf.

Sedangkan, abreviasi menurut Calvet (1999: 10) adalah pemenggalan kata yang sering terjadi pada bahasa popular dan bahasa argotic. Abreviasi digunakan untuk mempersingkat waktu dan mempermudah penulisan.

Proses abreviasi atau penyingkatan di dalam bahasa Prancis dibedakan menjadi abréviation dan siglaison.

1. Abréviation

"La phénomène de l'abreviation est particulière à la langue familière ou vulgaire, qui tends systématiquement à l'économie dans la pronunciation tout en conservant l'unité du signifié." (Béchade, 1992: 172)

Fenomena abreviasi adalah salah satu bentuk bahasa sehari-hari yang secara sistematis cenderung efisien dalam proses pengucapannya, namun tetap menjaga kesatuan maknanya

Krautganer (2003: 48) dalam jurnalnya yang berjudul 'Techniques d'abreviation dans les webchats francophones' menyebutkan beberapa jenis abreviasi dalam bahasa Prancis

a. Aphérèse merupakan proses penghilangan leksem pada awal kata, misalnya bus (autobus).

b. Apocope adalah proses penghilangan leksem pada akhir kata, misalnya célibataire (célib).

c. Syncope adalah proses penghilangan atau penanggalan satu atau beberapa leksem di tengah kata, contohnya adalah bd (boulevard), grd (grand). 
2. Siglaison

"La siglaison consiste dans la reduction d'un terme compose à la succession des initiales des termes qui le composent. Selon la pronunciation, on distingue siglès et acronymes." (Béchade, 1992: 173)

Siglaison dibentuk melalui pengekalan ucapan dari beberapa huruf awal yang membentuknya. Melalui bentuk pelafalannya, siglaison terbagi menjadi dua jenis yaitu siglè dan akronim.

a. Le siglè

Siglè merupakan proses penyingkatan yang terbentuk melalu pengekalan satu atau beberapa leksem awal dari masingmasing komponen atau kata serta dalam pelafalannya disesuaikan melakui huruf per hurufnya. Contoh:

RTT (Réduction du Temps de Travail)

b. L'acronyme

L'acronyme adalah proses penyingkatan yang terbentuk melalui pengekalan satu atau beberapa leksem awal dari masing-masing komponen dan dilafalkan seperti sebuah kata. Contoh:

UPTIH (Union Profesionnelle des Travailleurs Indépendents Handicapés)

\section{METODE}

Dalam penelitian ini, penulis menggunakan metode penulisan analisis deskriptif. Analisis deskriptif merupakan cara penelitian yang bertujuan mendeskripsikan atau menggambarkan secara sistematis mengenai data yang akan diteliti oleh penulis. Penelitian ini terdiri atas tiga tahap penelitian yaitu tahap penyediaan data, tahap analisis data, dan tahap penyajian hasil analisis

Penulis menggunakan metode penelitian menurut Sudaryanto (2016). Menurut Sudaryanto, metode penyediaan data dikelompokkan menjadi dua macam yaitu metode simak dan metode cakap. Pada penelitian ini, proses penyediaan data dilakukan dengan menggunakan metode simak dengan teknik catat

sebagai teknik dasarnya. Data diambil dari media sosial yaitu Twitter.

Penulis memperoleh data dengan cara menyimak tweet dari pengguna media sosial Twitter yang menggunakan bahasa Prancis. Setelah menyimak, penulis menandai tweet yang mengandung proses morfologis abreviasi. Adapun teknik catat dilakukan setelah menandai kalimat dengan mencatat bentuk yang relevan bagi penelitian.

Selanjutnya, metode yang digunakan untuk menganalisis data dalam penelitian ini adalah metode distribusional.

Selanjutnya, metode yang digunakan untuk menganalisis data dalam penelitian ini adalah metode distribusional. Proses analisis menggunakan metode kualitatif dengan kajian morfologi.

\section{HASIL DAN PEMBAHASAN}

Setelah melakukan analisis terhadap tweet berbahasa Prancis, penulis menemukan banyak proses abreviasi yang terjadi. Jenis abreviasi yang paling banyak terjadi adalah apocope, lalu diikuti oleh syncope, siglè, acronyme, dan yang paling sedikit adalah aphérèse.

\begin{tabular}{|ccc|}
\hline No & Jenis Abreviasi & $\begin{array}{c}\text { Jumlah } \\
\text { Data }\end{array}$ \\
\hline 1 & Aphérèse & 4 \\
2 & Apocope & 14 \\
3 & Syncope & 10 \\
4 & Siglè & 7 \\
5 & Acronyme & 5 \\
\hline & Total & 40 \\
\hline
\end{tabular}

Di bawah ini akan dideskripsikan hasil analisis dari data-data yang telah ditemukan 
Data 1

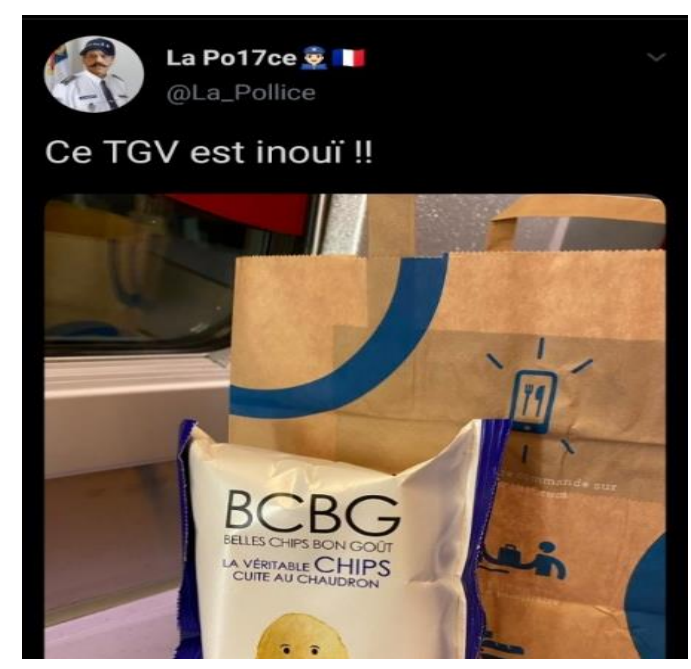

Gambar 1. Data 1

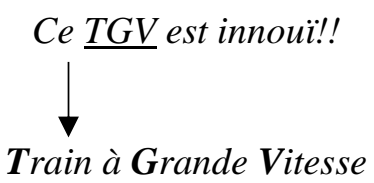

Pada data (1), terdapat jenis abreviasi yang disebut siglè, yaitu yang disebut singkatan. Hal ini tampak pada data TGV yang merupakan singkatan dari train grande vitesse 'kereta berkecepatan tinggi' yang terdapat di Prancis. TGV adalah kereta tercepat pertama di Eropa. TGV dikatakan sigle karena dalam pelafalannya dieja te-je-ve.

Data 2

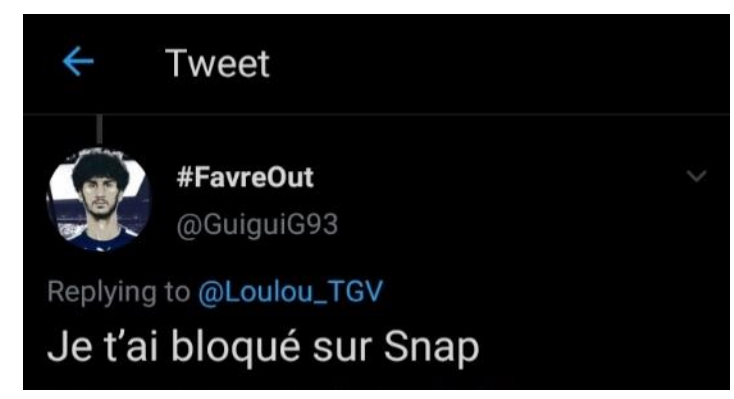

Gambar 2. Data 2

Je t'ai bloqué sur Snap

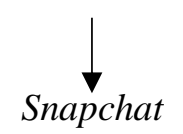

Pada data (2) terdapat kata Snap yang berasal dari kata Snapchat. Snapchat adalah sebuah aplikasi pesan foto, dengan aplikasi ini, pengguna dapat mengambil foto, merekam video, menambahkan teks dan lukisan, dan mengirimkannya ke daftar penerima yang ditentukan pengguna.

Pada kata tersebut, terjadi pemenggalan di akhir kalimat, hal ini ditandai dengan hilangnya 'chat' dari kata tersebut. Pemenggalan kata di akhir kata disebut apocope.

Data 3

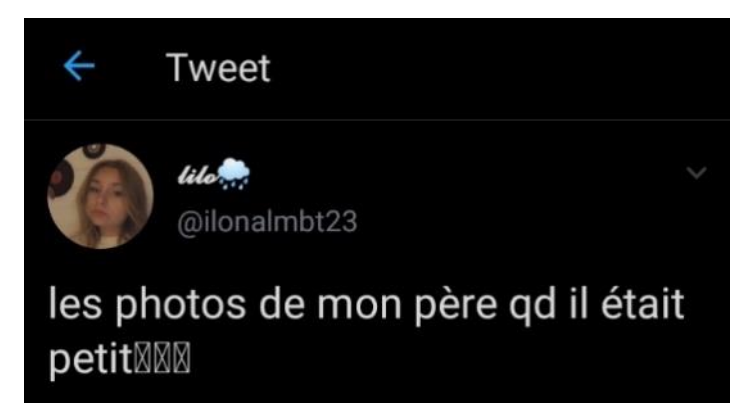

Gambar 3. Data 3

Les photos de mon père qd il était petit

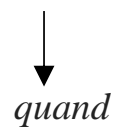

Pada data (3) terdapat kata qd yang merupakan singkatan dari kata quand 'ketika' yang termasuk ke dalam konjungsi subordinatif. Jenis abreviasi yang terjadi pada data tersebut adalah syncope, yakni pengurangan huruf pada pertengahan kata. Pada data (3) huruf $\mathrm{u}$, a, n, dan d yang terdapat pada pertengahan kata sengaja dihilangkan dan menghasilkan bentuk baru yaitu $q d$.

Data 4

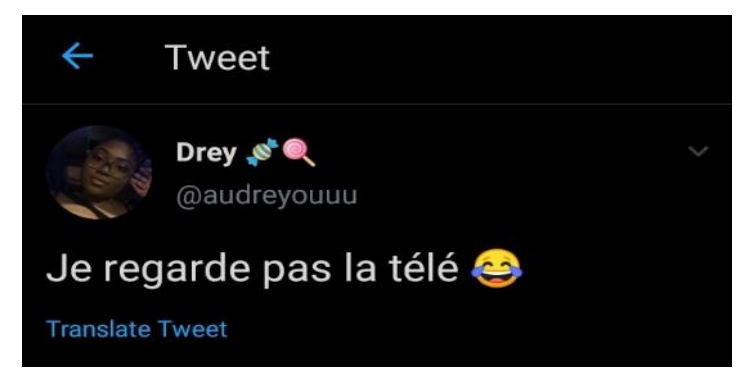

Gambar 4. Data 4

Je regarde pas la télé

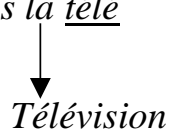




\section{1 | JURNAL ILMU BUDAY}

Volume 8, Nomor 1, Juni 2020

Pada data (4) terjadi proses morfologis yakni abreviasi yang berupa pemenggalan pada akhir kata atau biasa disebut apocope. Kata télé termasuk ke dalam kategori apocope karena adanya penghilangan dua suku kata terakhir yaitu vision. Kata télé berasal dari kata télévision yang berarti televisi.

Data 5

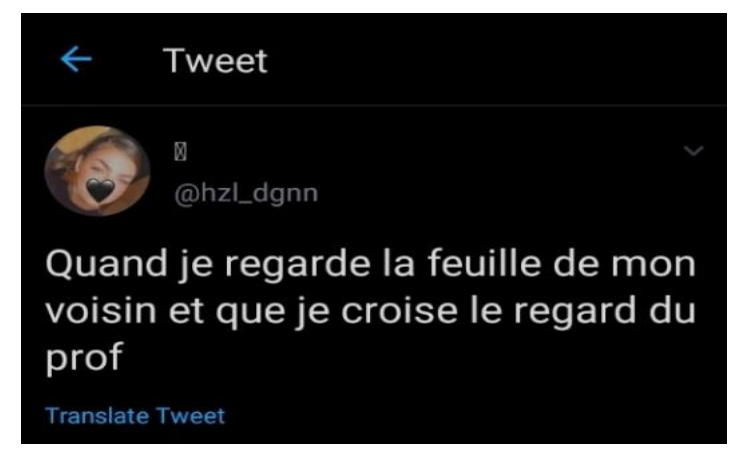

Gambar 5. Data 5

Quand je regarde la feuille de mon voisin et que je croise le regard du prof

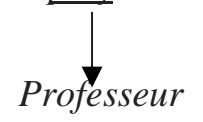

Pada data (5) terdapat kata prof yang merupakan bentuk singkat dari nomina professeur yang berarti guru atau pengajar. Pada data tersebut, terjadi proses pemenggalan kata di akhir kalimat, sehingga dapat didakatan bahwa data tersebut mengandung jenis abreviasi apocope.

Data 6

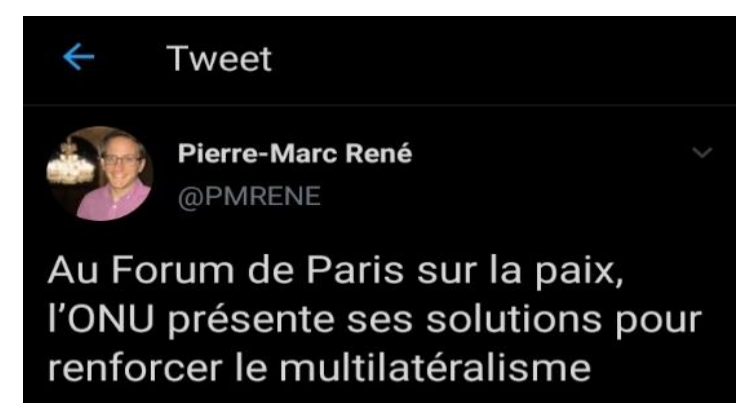

Gambar 6. Data 6

Au Forum de Paris sur la paix, l'ONU présente ses solutions pour renforcer le multilatéralisme.

Organisation des Nations Unies
Pada data (6) terdapat satu jenis abreviasi acronyme, hal ini dibuktikan dengan adanya pengekalan leksem awal dari masing-masing komponen yaitu huruf O dari kata Organisation, lalu huruf N dari kata Nations, dan huruf U dari kata Unies. Pelafalan kata ONU dilafalkan seperti sebuah kata. ONU (Organisation des Nations Unies) adalah nama singkatan dari sebuah organisasi internasional yang dalam bahasa Indonesia disebut PBB (Perserikatan Bangsa-Bangsa).

Data 7

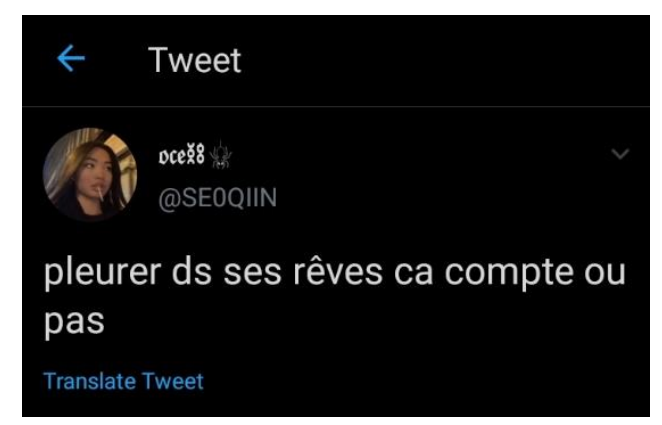

Gambar 7. Data 7

Pleurer $\underline{d s}$ ses rêves ca compte ou pas<smiles></smiles>

Pada data (7) terdapat kata $d s$ yang merupakan bentuk singkat dari preposisi dans 'di dalam'. Pada kata tersebut terjadi penghilangan beberapa huruf yang terdapat pada pertengahan kata sehingga hanya menyisakan huruf $\mathrm{d}$ dan $\mathrm{s}$, maka dapat disimpulkan bahwa data (7) mengalami jenis abreviasi syncope.

Data 8

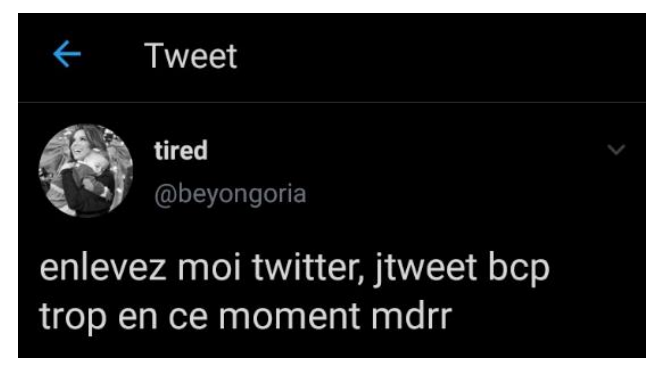

Gambar 8. Data 8

Enlevez moi twitter, je tweet bcp trop en ce moment $\underline{\text { mdrr }}$ 


\section{2 | JURNAL ILMU BUDAY}

Pada data (8), terdapat dua kata yang mengalami abreviasi yakni $b c p$ yang berasal dari kata beaucoup 'banyak' dan $m d r$ yang merupakan singkatan dari mort de rire.

Pada kata bcp, terdapat penghilangan beberapa huruf dari kata beaucoup sehingga dapat disimpulkan bahwa kata tersebut mengalami proses abreviasi yakni syncope.

Sedangkan, kata yang kedua yakni $m d r$ merupakan istilah yang biasa digunakan ketika melihat sesuatu yang sangat lucu. Dalam bahasa Inggris, terdapat istilah yang memiliki arti sama yaitu kata lol (laughing out loud). Pada kata $m d r$ terjadi penyingkatan yang terbentuk melalui pengekalan leksem awal dari masing-masing komponen, selain itu dalam pelafalannya kata $m d r$ dilafalkan sesuai huruf per hurufnya. Maka, dengan ciri-ciri tersebut, kata $m d r$ termasuk ke dalam kategori abreviasi siglè .

Data 9

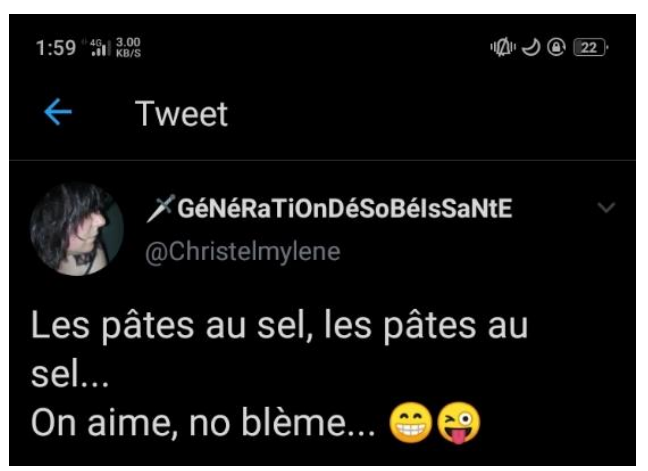

Gambar 9. Data 9

Les pâtes au sel, les pâtes au sel. On aime, no blème.

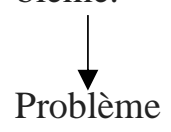

Pada data (9) terjadi proses abreviasi berupa pemenggalan pada awal kata atau biasa disebut aphérèse. Kata blème berasal dari nomina problème yang berarti masalah. Pada data (9), terdapat penghilangkan satu suku kata awal sehingga menghasilkan singkatan baru yaitu kata blème.

\section{SIMPULAN}

Setelah melakukan analisis pada 20 data berupa tweet berbahasa Prancis yang mengandung proses morfologis abreviasi, dapat ditemukan lima jenis abreviasi yang muncul, yaitu apocope, aphérèse, syncope, siglè, dan acronyme. Dari emmpat puluh data yang telah dikumpulkan dan dianalisis, terdapat 14 data yang mengandung apocope, 10 data yang mengandung syncope, 7 data yang mengandung siglè, 5 kata yang mengandung acronyme, dan 4 data yang mengandung aphérèse.

\section{DAFTAR PUSTAKA}

Andres Kaplan \& Michael HaenLein, (2010). User Of The World, Unite! The Challenges and Opportunities Of Social Media. Business Horizons

Kridalaksana. (2008). Kamus Linguistik. Jakarta: PT Gramedia Pustaka Utama

Gusti Ngurah Aditya Lesmana, Tesis: Analisis Pengaruh Media Sosial Twitter Terhadap Pembentukan Brand Attachment, Program Magister Manajemen, Fakultas Ekonomi, Universitas Indonesia. hal, 10-11

Juanita, D., Usman, M., \& Masdiana. (n.d.). Abreviasi Bahasa Indonesia dan Bahasa Prancis (Suatu Analisis Kontrastif). Retrieved from http://repository.unhas.ac.id/handle/1 23456789/25807

Moeschler, dkk. (2009). Introduction à la Linguistique Contemporaine. Paris: Armand Colin.

Nursella, A. (2016). Analyse des Abréviations et Sigles Dans Les Petites Annonces Françaises. HEXAGONE Jurnal Pendidikan, Linguistik, Budaya Dan Sastra Perancis, 5(1), 1-11. 


\section{3 | JURNAL ILMU BUDAYA}

Volume 8, Nomor 1, Juni 2020

https://doi.org/10.24114/hxg.v51.389

2

Salzburg, K. K. (2003). Techniques d'abréviation dans les webchats francophones. Linguistik Online, 15(3), 47-67. https://doi.org/10.13092/lo.15.815

Wulandari, A. (2016). Penggunaan Jargon Oleh Komunitas Chatting WhatApp Grup. 12 (September), 60-72. 